\title{
STRAIN DIFFERENCES IN CONCANAVALIN A-INDUCED PAW EDEMA IN THE RAT: INVOLVEMENT OF HISTAMINE $\mathrm{H}_{1}$ AND $\mathrm{H}_{2}$ RECEPTORS
}

KUŠTRIMOVIĆ NATAŠA*, MITIĆ KATARINA*, DIMITRIJEVIĆ MIRJANA*, VUJIĆ VESNA**, KOVAČEVIĆ-JOVANOVIĆ VESNA*, MILETIĆ TATJANA* and STANOJEVIĆ STANISLAVA*

*Immunology Research Centre "Branislav Janković", Institute of Virology, Vaccines and Sera "Torlak", Belgrade, Serbia

**Institute of Chemistry, School of Medicine, University Belgrade, Serbia

(Received 5 $5^{\text {th }}$ September 2010)

The present study tests the hypothesis that the difference in the intensity of paw edema found between the Dark Agouti (DA) and Albino Oxford (AO) rat strains originates from the distinct participation of histamine, serotonin and their corresponding receptors in Concanavalin A (Con A)-induced inflammation. DA and AO male rats were intraplantarly injected with specific receptor antagonists prior to Con $A$, and the intensity of inflammation was determined by measuring the paw diameter.

Our results have showed that histamine $H_{1}$ and $H_{2}$ receptor antagonists reduced the Con A-induced paw edema in $D A$ rats, while serotonin $5 \mathrm{HT}_{3}$ receptor antagonist diminished the inflammation in both $D A$ and $A O$ rat strains. The calcium channel blocker did not change Con A-induced inflammation.

Strain differences in the intensity and kinetics of inflammation observed between the $D A$ and $A O$ rats are most likely defined by the diversity of mediators released and their receptors activated upon Con A injection.

Key words: Albino Oxford $(A O)$ rat, antagonists, Concanavalin A (Con A), Dark Agouti (DA) rat, paw edema

\section{INTRODUCTION}

T cell mitogen concanavalin A (Con A), a glycan-binding protein isolated from the seeds of jack beans (Canavalia ensiformis), is widely used for in vitro studies of the mechanisms involved in T cells activation (Di Sabato et al., 1987). Con A in vivo stimulates T cell proliferation and activates macrophages (Deng et al., 1996), either via direct binding to macrophage surface (Barral-Netto and Barral, 1986) or by the activation of lymphocytes. Furthermore, Con A recruits cells to the peritoneal cavity (Rodriguez et al., 1992) and stimulates macrophage nitric oxide (NO) production (Andrade et al., 1999). Intravenous or retro-orbital application of Con A at substantially high doses $(10-30 \mathrm{mg} / \mathrm{kg}$ ) causes severe hepatitis in mice, characterized by the inflammatory infiltration (neutrophils, 
macrophages, and T cells) into the liver and the release of various cytokines, including tumor necrosis factor alpha (TNF $\alpha$ ) (Tiegs et al., 1992). In contrast, a non-hepatotoxic dose of Con A (3 mg/kg) induces high levels of interleukin (IL)-6 and prevents liver damage provoked by the high dose of Con A (Xu et al., 2006). Accordingly, Con A seems to be an activator of the immune system at multiple levels.

It has been reported that Con A injected in the footpads of mice and rats induces an intense and reproducible inflammatory response characterized by edema, erythema and induration at the site of the injection (Shier et al., 1974; Vujić-Redžić et al., 2000). The Con A-induced local inflammatory response is a valuable tool for rapid testing of potential anti-inflammatory drugs. However, we have observed significant strain differences in the intensity of Con A-induced paw edema in rats. Depending on the rat strain, the increase of paw diameter varies from $28 \%$ to $82 \%$ and reaches its maximum at different time points following the injection of Con A. Intraplantar, intraperitoneal or intracerebroventricular application of the opioid peptides methionine-enkephalin and $\beta$-endorphin, as well as anti- methionine-enkephalin antibodies and peptides belonging to the neuropeptide $Y$ family, also modulated the Con A-induced paw inflammation in rats, in a receptor- and strain- specific manner (Vujić-Redžić et al., 2000; Stanojević et al., 2006a; Stanojević et al., 2006b). Although several mechanisms underlying inflammatory action of Con $A$ have been proposed, including histamine and serotonin release, mediators involved in Con A inflammation have not been studied extensively.

Histamine is an early mediator of inflammation released from basophiles, mast cells and platelets, mainly responsible for formation of edema. Histamine induces various cellular responses via $\mathrm{H}_{1}$ receptors on vascular endothelial cells including changes in vascular permeability as a result of cell contraction, secretion and/or surface expression of mediators of inflammation (prostacyclin, platelet-activating factor and leukotiene B4) and NO release (Leurs et al., 2002). Histamine stimulates endothelial cells to express the adhesion molecules by activating both the $\mathrm{H}_{1}$ and $\mathrm{H}_{2}$ receptors (Kubes and Kanwar, 1994), and consequently stimulates endothelial-neutrophil adhesion. Delayed effects of histamine on endothelial cells comprise $\mathrm{H}_{1}$ receptor-mediated increase in the mRNA expression and secretion of neutrophil-attracting chemokine IL-8 (Jeannin et al., 1994). Furthermore, $H_{1}$ receptors mediate the histamine-induced stimulation of respiratory burst in neutrophils (Benbarek et al., 1999) and the increase in production of proinflammatory cytokine IL-6 in macrophages (Triggiani et al., 2001). In addition, histamine exerts its proinflammatory effects via histamine $\mathrm{H}_{4}$ receptors expressed on mast cells, dendritic cells, monocytes, eosinophils and lymphocytes (Huang and Thurmond, 2008). Due to their high affinity to histamine, (i.e. 1000 fold greater than the $\mathrm{H}_{1}$ receptors'), the $\mathrm{H}_{4}$ receptors respond to lower histamine doses released by both immunological and nonimmunological stimuli. In contrast, the activation of $\mathrm{H}_{1}$ receptors requires high concentration of histamine, like those typically found in inflammation immediately upon mast cell degranulation. It has been shown that histamine exerts antiinflammatory activities, as well. Namely, histamine stimulates the synthesis of anti- 
inflammatory cytokine IL-10 via $\mathrm{H}_{2}$ receptors (Sirois et al., 2000) and inhibits the synthesis of pro-inflammatory IL-12 (van der Pouw Kraan et al., 1998), IL-18 and TNF $\alpha$ (Yokoyama et al., 2004). Furthermore, $\mathrm{H}_{2}$ receptors have been shown to negatively regulate the release of histamine from basophils and mast cells (Lichtenstein et al., 1975).

Serotonin is a major neurotransmitter component of the inflammatory chemical milieu, and may be released from platelets, mast cells, lymphocytes, monocytes, macrophages and basophils that infiltrate areas of tissue damage; in fact, platelets and mast cells can be viewed as mobile and stationary storage cells for serotonin, respectively (Dray, 1995). Serotonin exerts similar proinflammatory effects as histamine. A number of serotonin (5-hydroxytryptamine) receptor classes $\left(5 \mathrm{HT}_{1}-5 \mathrm{HT}_{7}\right)$ have been identified in peripheral neuronal and nonneuronal tissues. Serotonin $5 \mathrm{HT}_{3}$ receptor takes a special place as phylogenetically much older, and as the only ligand-gated cation channel receptor among the other serotonin receptors (Färber et al., 2004). It was proposed that serotonin $5 \mathrm{HT}_{3}$ receptors are exclusively neuronal, both centrally and peripherally (Fozard, 1984). However, $5 \mathrm{HT}_{3}$ receptors were also detected on immune cells, especially upon Con A stimulation (Fiebich et al., 2004a; Stefulj et al., 2000). Additionally, some specific $5 \mathrm{HT}_{3}$ receptor antagonists displayed antiinflammatory activity (Fiebich et al., 2004b).

In view of these facts, the present study was set up to test the hypothesis that the difference in the intensity of paw edema in Dark Agouti (DA) and Albino Oxford (AO) rat strains originates from the distinct participation of histamine, serotonin and their corresponding receptors in Con A-induced inflammation. The involvement of histamine and serotonin in Con A-induced paw edema was investigated by the use of antagonists specific for histamine $\mathrm{H}_{1}$ and $\mathrm{H}_{2}$ and serotonin $5-\mathrm{HT}_{3}$ receptors. Since $\mathrm{Ca}^{2+}$ ions participate in the release of inflammatory mediators (De Vries et al., 1995; Rodler et al., 1995) and the release of peripheral nerves neurotransmitters involved in the control of local inflammatory millieu (Augustin, 2001), a specific calcium channel blocker was also utilized.

\section{MATERIALS AND METHODS}

\section{Animals}

Seven months old DA and $A O$ male rats were obtained from our breeding colony at Immunology Research Center "Branislav Janković", Belgrade. Animals were housed individually in perspex-walled cages with free access to food and water. Colony conditions were maintained using $12 \mathrm{~h}$ light and $12 \mathrm{~h}$ dark cycles (lights on at 08:00). All procedures involving animals were approved by the Institutional Animal Care and Use Committee and followed the guidelines described in the European Community's Council Directive dated 24th November $1986(86 / 609 / \mathrm{EEC})$.

\section{Drugs}

Specific antagonists for histamine $\mathrm{H}_{1}$ receptors (Chloropyramine hydrochloride; N-p-Chlorobenzyl-N', N'-dimethyl-N-(2-pyridyl) ethylenediamine; 
Chl) and antagonist for serotonin $5 \mathrm{HT}_{3}$ receptors (Granisetron hydrochloride ${ }^{\circledR}$; Gran) were purchased from Pliva, Croatia. Histamine $\mathrm{H}_{2}$ receptor antagonist (Ranitidine hydrochloride ${ }^{\circledR}$; Ran) was obtained from Remevita, Serbia. Calcium channel antagonist verapamil hydrochloride (5-(N-(3,4-Dimethoxyphenylethyl) methylamino)-2-(3,4-dimethoxyphenyl)-2-isopropylvaleronitrile hydrochloride; Ver) was obtained from Galenika, Serbia (Izopamil®). Concanavalin A (isolated from Canavalia ensiformis, type III) was acquired from Sigma (St. Louis, Mo., USA). All the drugs were dissolved in sterile, apyrogenic saline prepared from purified water (with endotoxin units below the level of detection according to limulus amoebocyte lysate (LAL) assay, Torlak Institute in Belgrade).

\section{Induction of inflammation and treatments}

Inflammatory edema was induced by a single intraplantar (i.pl.) injection (i.e. into the dorsal part of the metatarsal region of hind paws) of Con $\mathrm{A} \mathrm{pH} 7$ ( $8 \mathrm{mg} / \mathrm{mL}$ saline, $400 \mu \mathrm{g}$ Con A in $50 \mu \mathrm{L}$ per paw).

Antagonists specific for histamine $\mathrm{H}_{1}$ (chloropyramine) and $\mathrm{H}_{2}$ (ranitidine), receptors, and calcium channel blocker (verapamil) were intraplantarly injected at the dose of $100 \mu \mathrm{g}$ per paw ( $2 \mathrm{mg} / \mathrm{mL}$ saline, $50 \mu \mathrm{L}$ per paw) 30 minutes prior to Con A, while the control animals were injected with $50 \mu \mathrm{L}$ of saline per paw 30 minutes prior to Con $\mathrm{A}$. The antagonist specific for serotonin $5 \mathrm{HT}_{3}$ receptors (granisetron) was injected at $50 \mu \mathrm{g}$ per paw $(1 \mathrm{mg} / \mathrm{mL}$ saline, $50 \mu \mathrm{L}$ per paw) in the same manner. Separate groups of rats were i.pl. treated with $50 \mu \mathrm{L}$ of the specific receptor antagonists or saline in the absence of inflammation.

To minimize animal discomfort during handling and i.pl. treatments, the rats were briefly (1-3 min) exposed to isoflurane vapor and closely monitored for the occurrence of early signs of sedation observed as behavioral tranquility and calmness. This procedure permitted full recovery within a minute after the treatment.

As maximal increase of paw diameter occurred $12 \mathrm{~h}$ and $9 \mathrm{~h}$ after induction of inflammation in DA and AO rats, respectively, the intensity of inflammation was determined by measuring the diameter of the tarso-metatarsal joints using a nonius before, and $3,6,12$, and $24 \mathrm{~h}$ after induction in DA rats and before, and 3 , 6, 9 and $24 \mathrm{~h}$ after induction in AO rats. The number of rats per group was 6-8.

The results are expressed as relative increase of paw diameter (\%) according to the formula:

$d$ rel $=((d$ after injection $-d$ before injection $) / d$ before injection $) \times 100$

\section{Statistical analysis}

Statistical analysis of the data was performed using the SPSS 10.0 computer programme. The results were analyzed by one-way ANOVA and Student's independent samples t-test. LSD and Scheffe tests were used for post hoc analysis for the evaluation of the differences between independent groups. In the figures, all data are displayed as mean \pm (S.E.M.). 


\section{RESULTS}

\section{Development of Con A-induced paw inflammation}

Both rat strains developed inflammatory edema upon Con $A$ injection that was observed $24 \mathrm{~h}$ post-induction (Fig. 1). Local Con A injection did not cause a spontaneous pain behavior in either of the strains, as judged by the absence of limping or guarding of the affected hindpaws. As in our previous study (Stanojević et al., 2006a), a maximal increase of paw diameter was observed $12 \mathrm{~h}$ after the Con A injection in DA rats, reaching the levels of $70 \%$ increase over the controls injected only with saline (Fig. 1, upper panel). AO rats exhibited substantially a lower degree of paw inflammation reaching $40 \%$ of increase in paw diameter $9 \mathrm{~h}$ after the induction with Con A (Fig. 1, lower panel). Some degree of tissue swelling was observed in rats of $\mathrm{AO}$ strain during the first hours following the injection with saline.

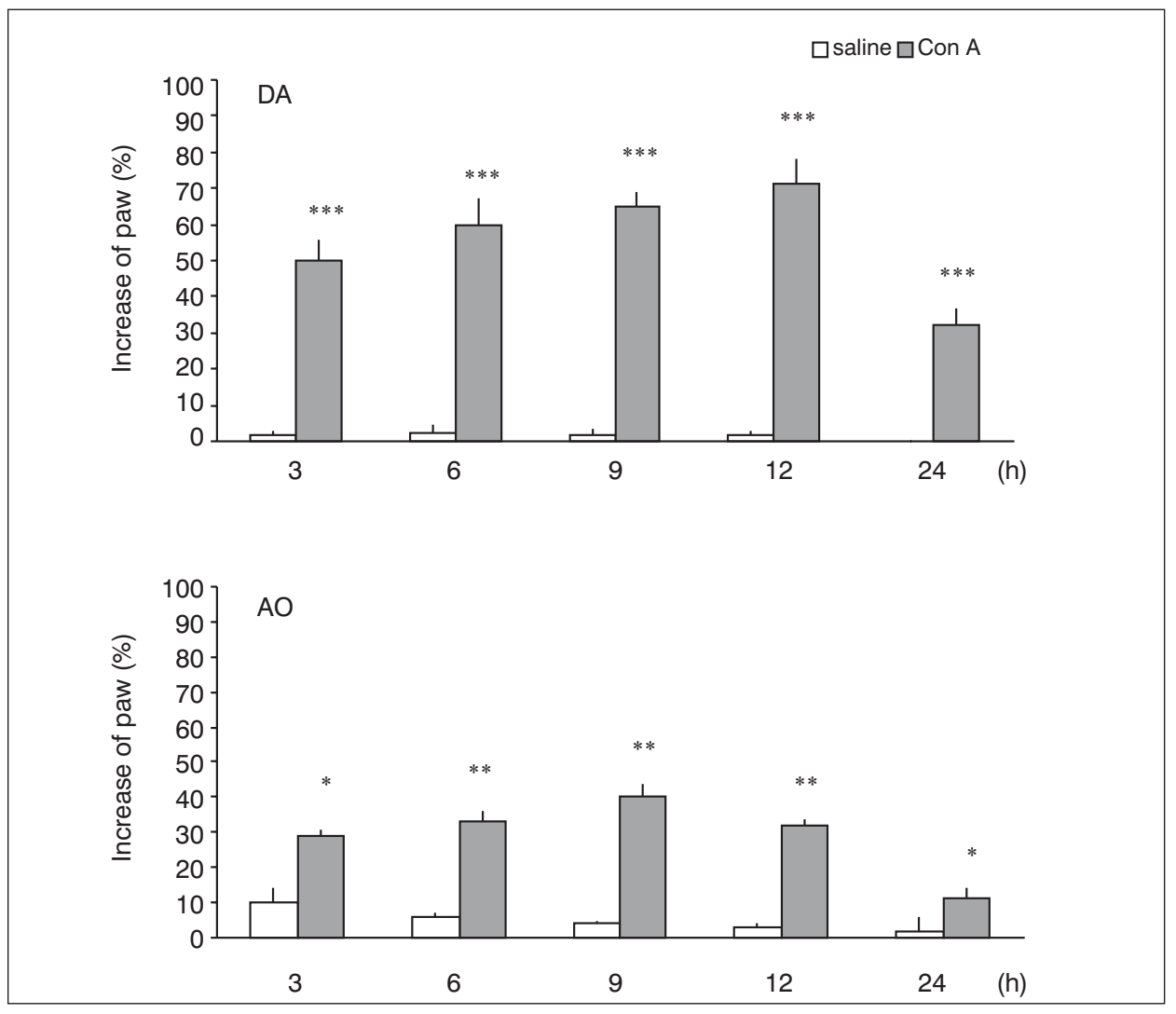

Figure 1. Development of Concanavalin A (Con A)-induced paw edema in rats of DA (upper panel) and AO (lower panel) strains. Values represent mean \pm SE. Statistically significant differences: * $p<0.01 ;{ }^{* \star} p<0.001$; and ${ }^{* \star *}, p<0.0001$ vs. saline 
The effect of histamine receptor antagonists on Con A-induced paw inflammation

In DA rats, the $\mathrm{H}_{1}$ receptor antagonist chloropyramine decreased paw diameter up to $12 \mathrm{~h}$ following the Con $\mathrm{A}$ injection, while the $\mathrm{H}_{2}$ receptor antagonist ranitidine decreased it at all time points (Fig. 2, upper panel). In rats of the $A O$ strain, the i.pl. injection of chloropyramine gradually increased inflammation following the pattern of Con A induced paw swelling, but with much higher intensity (more than $80 \%$ of increase over the control $9 \mathrm{~h}$ post-injection, compared to $40 \%$ in Con A-treated paws) and remained effective even $24 \mathrm{~h}$ after injection (Fig. 2, lower panel). Histamine $\mathrm{H}_{2}$ receptor antagonist ranitidine exerted proinflammatory activity as early as $3 \mathrm{~h}$ after the Con A injection in $\mathrm{AO}$ rats that remained relatively unchanged for the next 6 hours and returned to the control values within $24 \mathrm{~h}$.

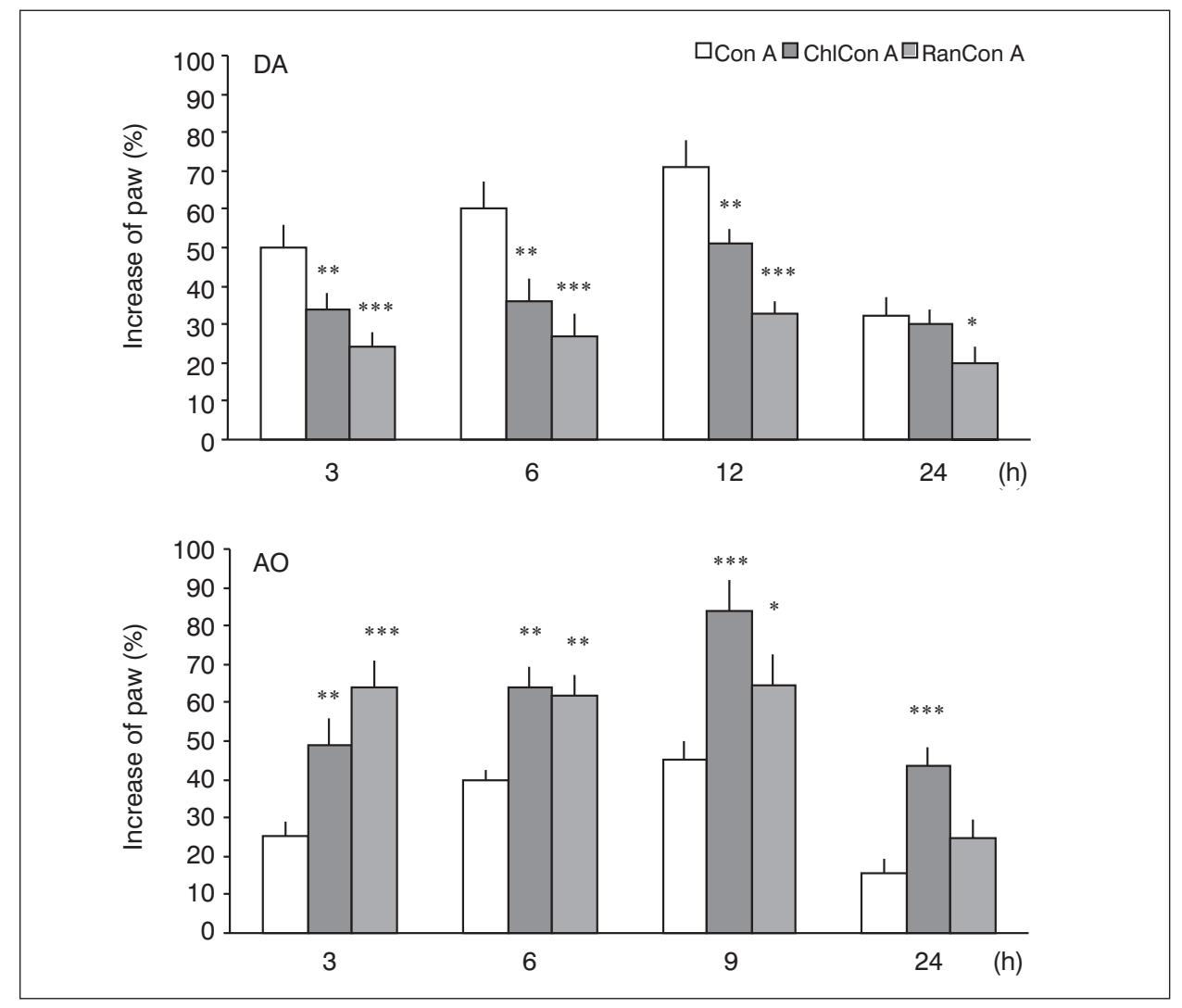

Figure 2. The effect of i.pl. injection of $100 \mu \mathrm{g}$ of chloropyramine (Chl) and ranitidine (Ran) on development of paw edema induced by Con A in rats of DA (upper panel) and AO (lower panel) strains. Values represent mean \pm SE. Statistically significant differences: * $p<0.05 ;{ }^{* *} p<0.01$; and ${ }^{* * *} p<0.0001$ vs. Con A 
Acta Veterinaria (Beograd), Vol. 61, No. 2-3, 119-132, 2011.

Kuštrimović Nataša et al.: Strain differences in Concanavalin A-induced

paw edema in the rat: involvement of histamine $\mathrm{H}_{1}$ and $\mathrm{H}_{2}$ receptors

The effect of $\mathrm{Ca}^{2+}$ channel blocker and serotonin $5 \mathrm{HT}_{3}$ receptor antagonist on Con A-induced paw inflammation

$\mathrm{Ca}^{2+}$ channel blocker verapamil enlarged the Con A-induced paw edema in DA rats $6 \mathrm{~h}$ after inflammation induction, while serotonin $5 \mathrm{HT}_{3}$ receptor antagonist granisteron decreased paw diameter 12 and 24 hours after Con A injection (Fig. 3, upper panel). In AO rats, verapamil suppressed inflammation only $24 \mathrm{~h}$ after Con A injection, while granisteron decreased Con A-induced inflammation 6, 9 and $24 \mathrm{~h}$ post-induction (Fig. 3, lower panel).
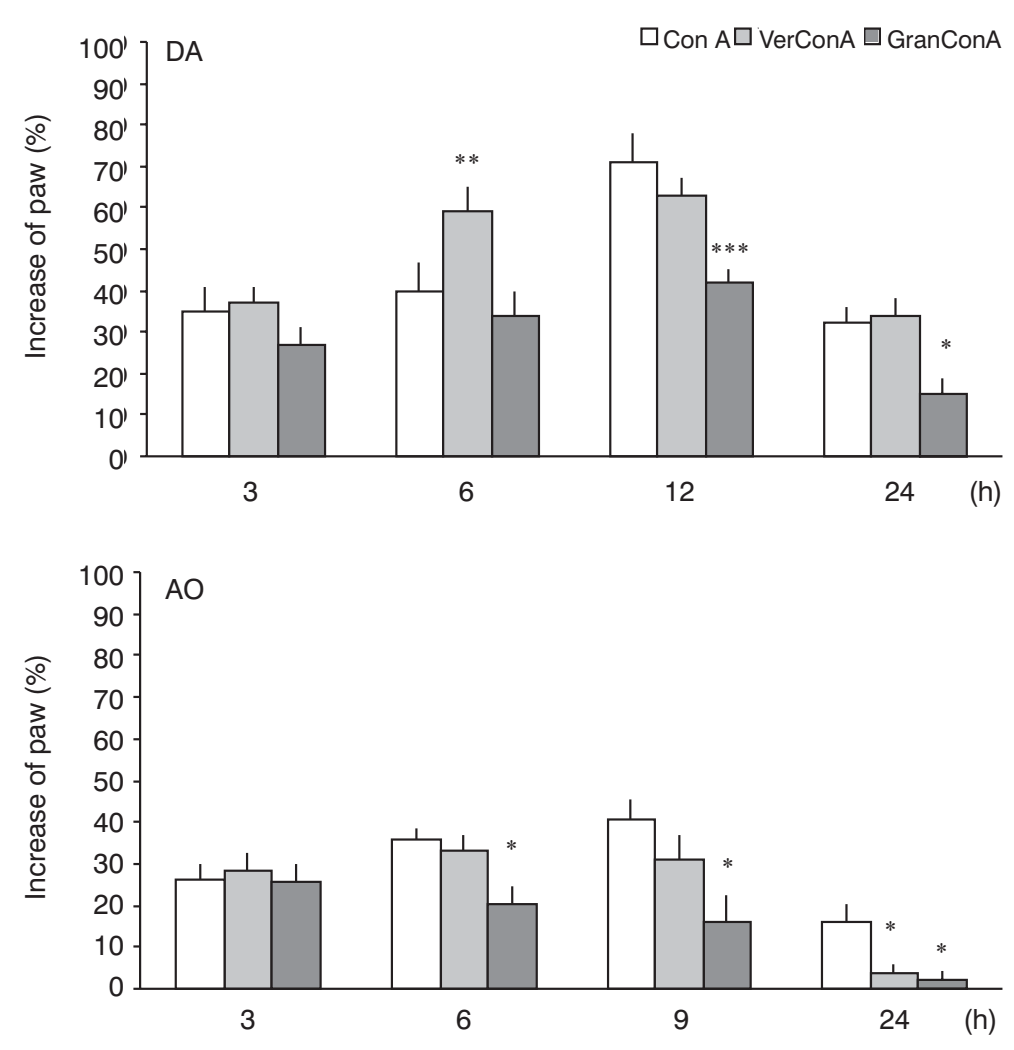

Figure 3. The effect of i.pl. injection of $100 \mu \mathrm{g}$ of verapamil (Ver) and $50 \mu \mathrm{g}$ of granisetron (Gran) on development of paw edema induced by Con A in rats of DA (upper panel) and $A O$ (lower panel) strains. Values represent mean \pm SE. Statistically significant differences: ${ }^{*} p<0.01 ;{ }^{*} p<0.001$; and ${ }^{\star \star *} p<0.0001$ vs. Con $A$

The effect of histamine receptor antagonists, $\mathrm{Ca}^{2+}$ channel blocker and serotonin $5 \mathrm{HT}_{3}$ receptor antagonist on the diamater of non-inflamed paws

In DA rats all the antagonists exerted an edema-promoting effect. In AO rats, chloropyramine and ranitidine increased paw diameter relative to saline-injected 
paws, while verapamil and granisetron did not have any effect on the noninflamed paws. Actually, the level of the increase of the paw diameter induced by verapamil and granisetron was comparable in two rat strains, but the increase induced by saline was higher in $\mathrm{AO}$ rats resulting in the absence of the statistical differences in verapamil and granisetron versus saline in this strain. Figure 4 shows representative results, i.e. $12 \mathrm{~h}$ post injection in DA and $9 \mathrm{~h}$ post injection in $\mathrm{AO}$ rats.

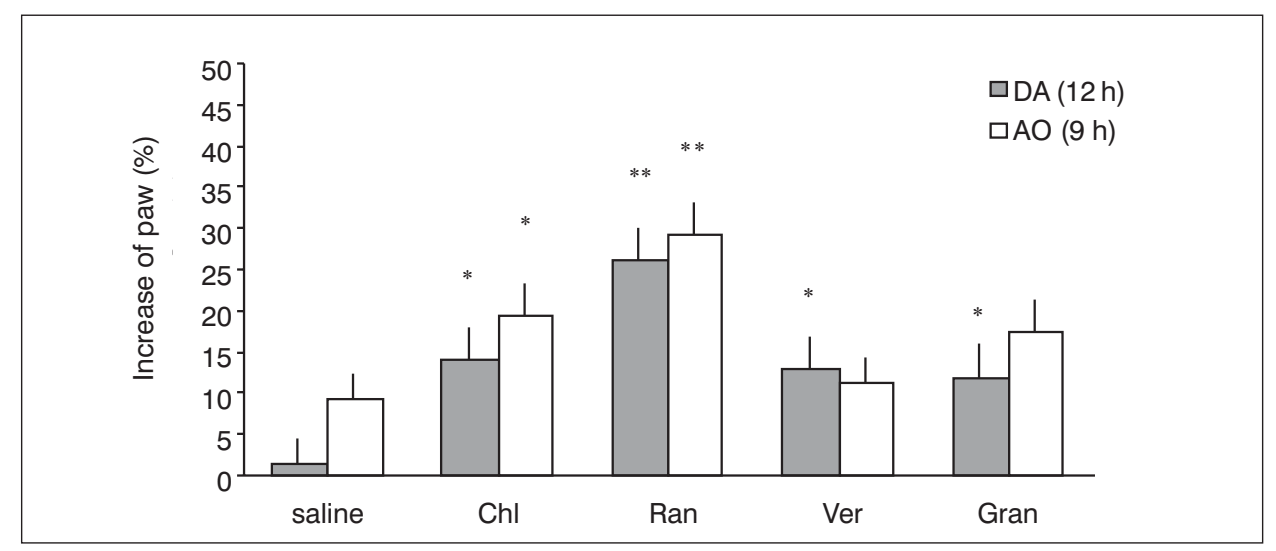

Figure 4. The effect of i.pl. injection of $100 \mu \mathrm{g}$ of chloropyramine (Chl), ranitidine (Ran) and verapamil (Ver), and $50 \mu \mathrm{g}$ of granisetron (Gran) on the diameter of the non-inflamed paws of DA and $A O$ rat strains. Values represent mean \pm SE. Statistically significant differences: ${ }^{\star} p<0.05$ and ${ }^{* \star} p<0.001$ vs. saline

\section{DISCUSSION}

The present study reflects the results from our previous experiments, in which the i.pl. injected Con A exerted the edema-promoting effects in both rat strains, with a substantially stronger intensity of inflammation in DA than in rats of the AO strain (Stanojević et al., 2006a). Con A increases microvascular permeability directly by binding to endothelial cells (Northover and Northover, 1994), but also indirectly by inducing histamine release from mast cells (Lopes et al., 2005), which induces plasma extravasation at the post-capillary venules. This is supported by the suppression of paw edema with antagonists of histamine $\mathrm{H}_{1}$ and $\mathrm{H}_{2}$ receptors in DA rats. It is in line with previous reports that $\mathrm{H}_{1}$ and $\mathrm{H}_{2}$ histamine receptor antagonists partially blocked zymosan-induced plasma exudation, and $\mathrm{H}_{1}$ receptor antagonists reduced neutrophil influx (Kolaczkowska et al., 2001).

Histamine effects are mostly related to a rapid increase in vascular permeability, but in our model histamine antagonists were effective in blocking the paw edema development up to $24 \mathrm{~h}$ after the Con A injection. Accordingly, some histamine-liberating substances induce maximal paw edema at the moment when 
histamine content already returned to the basal levels (Guo et al., 1997). This could be explained by the fact that gap formation in endothelial cells elicited by histamine may persist longer than the metabolism of histamine. In addition, some histamine effects might be related to a continuous histamine release. Although the richest source of endogenous histamine are mast cells located around vascularized tissues and nerves, in which granule-stored histamine is rapidly and transiently liberated upon activation, it was shown that macrophages, T cells and neutrophils, cells that are readily found in the inflammatory foci, can also produce and release histamine, but in a rather continuous manner (Yokoyama et al., 2004; Tanaka and Ichikawa, 2006). Along with many other inflammatory and immune mediators, histamine and serotonin can also stimulate peptidergic afferent nerve fibers or enhance their excitability and release vasoactive peptides, and in that sense indirectly prolong inflammation (i.e. calcitonin gene related peptide induces neurogenic dilatation of arterioles, substance $\mathrm{P}$ and neurokinins increase venular permeability) (Holzer, 1998).

Since the differentiation of monocytes into macrophages enhances $\mathrm{H}_{1}$ and suppresses $\mathrm{H}_{2}$ receptors expression (Wang et al., 2000), the more prominent involvement of $\mathrm{H}_{2}$ histamine receptors during the Con A-induced inflammation might point to a greater contribution of less mature (i.e. inflammatory) monocytes in rats of the DA strain.

In contrast, histamine was not the primary inflammatory agent implicated in the response induced by Con A in AO strain rats. Rather, it served to constrain inflammation development as judged by aggravation of inflammation following the pretreatment with both of the specific antagonists. As histamine inhibits the synthesis and/or LPS-induced release of TNF $\alpha$ in monocytes, while $\mathrm{H}_{2}$ receptor antagonist ranitidine increases the release of TNF $\alpha$ from mast cells (Bissonnette, 1996), it has been suggested that histamine acts as an autocrine regulator of TNFá release, through histamine $\mathrm{H}_{2}$ receptors. Furthermore, histamine also suppresses recruitment of neutrophils and macrophages upon ischemia/ reperfusion injury, air-pouch and pleural inflammation (Hiraga et al., 2007; Hirasawa et al., 1991), acting via $\mathrm{H}_{2}$ receptors. The administration of $\mathrm{H}_{2}$ receptor antagonists induces an increase of neutrophil infiltration (Hirasawa et al., 2002). Inspite of general inflammation-promoting effects of $\mathrm{H}_{1}$ receptors, it has been also shown that histamine via $\mathrm{H}_{1}$ receptors downregulates IL-12p70 production in stimulated dendritic cells (Gutzmer et al., 2002). In that sense, a local application of histamine $\mathrm{H}_{1}$ and $\mathrm{H}_{2}$ receptor antagonists might counteract antiinflammatory effects of histamine in $\mathrm{AO}$ rats and aggravate inflammation. $\mathrm{H}_{1}$ and $\mathrm{H}_{2}$ antagonists might nonspecifically liberate a variety of inflammatory mediators from mast cells and thus indirectly augment lectin-induced inflammation.

We have shown that serotonin was involved in the Con A-induced paw edema in both rat strains via $5 \mathrm{HT}_{3}$ receptors, since their blockade significantly decreased paw diameter in the peak and late phases of inflammation in DA rats, and in early, peak and late phase of inflammation in $A O$ rats. Specific $5 \mathrm{HT}_{3}$ receptors were detected on immune cells, especially upon Con A stimulation (Fiebich et al., 2004a; Stefulj et al., 2000). In addition, 5 $\mathrm{HT}_{3}$ receptors are present on capsaicin-sensitive sensory nerves and following their activation with serotonin 
they increase the release of inflammatory neuropeptides and in that way promote inflammation (Hua and Yaksh, 1993). Nevertheless, the $5 \mathrm{HT}_{3}$ receptor antagonists exerted an antiinflammatory effect by inhibition of TNF $\alpha$ and IL-1 $\beta$ release from human monocytes (Fiebich et al., 2004b). It seems that in Con A-induced inflammation model resident immune cells in concert with those recruited to the inflammation site can release serotonin, which binds to $5 \mathrm{HT}_{3}$ receptors and in autocrine/paracrine way regulates and increases cytokine production in situ. The effect of serotonin on $5 \mathrm{HT}_{3}$ receptors present on primary afferents in the inflammatory focus can not be excluded.

The release of histamine and serotonin from mast cells is a $\mathrm{Ca}^{2+}$ dependant process (Suzuki-Nishimura et al., 1989). Besides, it has been reported that development of carrageenan-induced edema (Khaksari et al., 1999) and skin inflammation (De Vries et al., 1995) in rats, as well as serotonin-induced paw edema in mice (Cole et al., 1995) were blunted by $\mathrm{Ca}^{2+}$ antagonist. Con A induces a rapid initial increase in intracellular concentration of $\mathrm{Ca}^{2+}$ and successive $\mathrm{Ca}^{2+}$ influx through $\mathrm{Ca}^{2+}$ channels (Ikegami et al., 1991). Accordingly, we have expected that $\mathrm{Ca}^{2+}$ channel blocker verapamil could inhibit the increase in paw diameter in Con A induced-inflammation. The finding that verapamil did not affect paw inflammation in $\mathrm{AO}$ rats supports the notion that only intracellular $\mathrm{Ca}^{2+}$ is required for mast cell histamine/serotonin release (Truneh and Pearce, 1981). In contrast, the aggravation of paw swelling in DA rats following a treatment with verapamil suggests its proinflammatory action. Several proinflammatory effects of verapamil were described, such as stimulation of NO production (Sirmagul et al., 2004) and rise in IL-6 production and successive increase in vascular permeability (Rodler et al., 1995).

Although saline should be devoid of any inflammatory activity, the finding that saline induced a slight paw edema in AO, but not in DA rats most likely revealed strain differences in mast cell membrane stability. It has been reported that trauma induced by needle penetration can activate small fiber sensory neurons to release proinflammatory and proanalgesic substance P, neurokinins and calcitonin gene-rated peptide and consequently cause a discharge of mast cell inflammatory mediators (Guo et al., 1997). Saline injection induced a significant increase in histamine release, but the level of histamine returned to control values during the next 2 hours (Guo et al., 1997). In addition, the saline injected into the upper surface of the rat paw in our experimental model could disturb the organization of the subcutaneous tissue, e.g. by inducing an increase in the thickness of connective tissue, separation of collagen fibers, and dilatation of blood and lymphatic vessels (Daitoku et al., 2007), therefore contributing to a transient edema formation in $\mathrm{AO}$ rats.

All antagonists used in our study increased the paw diameter in both rat strains if injected in the non-inflamed paws. Such a uniform edema-promoting behavior of antagonists is probably not due to the blockage of specific receptors and prevention of binding of endogenous ligands, but rather to some unspecific activity. As antagonists were injected at the dose of $100 \mu \mathrm{g}$ per paw, except granistreon (50 $\mu \mathrm{g}$ per paw), and their actual concentrations ranged from 3 to $7 \mathrm{x}$ $10^{-3} \mathrm{M}$ in tissue, it is most likely that their high concentration although safe for 
Acta Veterinaria (Beograd), Vol. 61, No. 2-3, 119-132, 2011.

systemic application, exerted a damaging effect if injected locally in the paws. In presence of inflammation, the primary proinflammatory effect of antagonists was probably shifted towards the receptor-specific antagonistic activity against mediators released following Con-A injection.

In general, our results showed that histamine mediated Con A-induced paw edema in DA rats via $\mathrm{H}_{1}$ and $\mathrm{H}_{2}$ receptors, while serotonin participated in inflammation in both $\mathrm{DA}$ and $\mathrm{AO}$ strains via $5 \mathrm{HT}_{3}$ receptors. Since histamine and serotonin are co-stored and co-released from mast cells, it seems that strain differences in Con A-induced inflammation may originate from different receptor subtypes expressed on vascular endothelial cells in AO and DA rats. Extracellular calcium ions were not involved in Con A-induced inflammation.

Strain differences found in the intensity and kinetics of inflammation between DA and AO rats are most likely defined by the diversity of mediators released and their receptors activated upon Con $A$ injection. While still bearing in mind the individual variations in building the inflammatory response, the model of Con A-induced rat paw edema can be quite useful for determining the antiinflammatory potency of different pharmacological substances.

\section{ACKNOWLEDGEMENTS:}

This work was supported by Grant No 145049 by the Ministry of Science Republic of Serbia, Belgrade, Serbia.

Address for correspondence:

Kuštrimović Nataša

Immunology Research Centre "Branislav Janković"

Institute of Virology, Vaccines and Sera "Torlak"

11000 Belgrade, Serbia

E-mail: natasa.kustrimovic@gmail.com

\section{REFERENCES}

1. Andrade JL, Arruda S, Barbosa T, Paim L, Ramos MV, Cavada BS et al., 1999, Lectin-induced nitric oxide production, Cell Immunol, 194, 98-102.

2. Augustine GJ, 2001, How does calcium trigger neurotransmitter release? Curr Opin Neurobiol, 11, 320-6.

3. Barral-Netto M, Barral A, 1986, A simple method for assessing the binding of concanavalin A to mononuclear cell surfaces: no interference of visceral leishmaniasis serum on this binding, Mem Inst Oswaldo Cruz, 81, 343-5.

4. Benbarek H, Mouithys-Mickalad A, Deby-Dupont G, Deby C, Grülke S, Nemmar A et al., 1999, High concentrations of histamine stimulate equine polymorphonuclear neutrophils to produce reactive oxygen species, Inflamm Res, 48, 594-601.

5. Bissonnette $E Y, 1996$, Histamine inhibits tumor necrosis factor alpha release by mast cells through $\mathrm{H}_{2}$ and $\mathrm{H}_{3}$ receptors, Am J Respir Cell Mol Biol, 14, 620-6.

6. Cole HW, Brown CE, Magee DE, Magee C, Roudebush RE, Bryant HU, 1995, Serotonin-induced paw edema in the rat: pharmacological profile, Gen Pharmacol, 26, 431-6.

7. Daitoku D, Kurose T, Mori E, Hashimoto M, Kawamata S, 2007, Changes in the rat subcutaneous connective tissue after saline and histamine injection in relation to fluid storage and excretion, Arch Histol Cytol, 70, 29-41. 
8. De Vries GW, McLaughlin A, Wenzel MB, Perez J, Harcourt D, Lee G, et al., 1995, The antiinflammatory activity of topically applied novel calcium-channel antagonists, Inflammation, $19,261-75$.

9. Deng X, Wang X, Andersson R, 1996, Alterations in endothelial barrier permeability in multiple organs during overactivation of macrophages in rats, Shock, 6, 126-33.

10. Di Sabato G, Hall JM, Thompson L, 1987, T cell mitogens and polyclonal B cell activators, Methods Enzymol, 150, 3-17.

11. Dray A, 1995, Inflammatory mediators of pain, Br J Anaesth, 75, 125-31.

12. Färber L, Haus U, Spath M, Drechsler S, 2004, Physiology and pathophysiology of the $5-\mathrm{HT}_{3}$ receptor, Scand J Rheumatol Suppl, 2-8.

13. Fiebich BL, Akundi RS, Lieb K, Candelario-Jalil E, Gmeiner D, Haus $U$ et al., 2004b, Antiinflammatory effects of $5-\mathrm{HT}_{3}$ receptor antagonists in lipopolysaccharide-stimulated primary human monocytes, Scand J Rheumatol Suppl, 28-32.

14. Fiebich BL, Akundi RS, Seidel M, Geyer V, Haus U, Muller W et al., 2004a, Expression of 5- $\mathrm{HT}_{3 \mathrm{~A}}$ receptors in cells of the immune system, Scand J Rheumatol Suppl, 9-11.

15. Fozard JR, 1984, Neuronal 5-HT receptors in the periphery, Neuropharmacology, 23, 1473-86.

16. Guo Y, Mochizuki T, Morii E, Kitamura Y, Maeyama K, 1997, Role of mast cell histamine in the formation of rat paw edema: a microdialysis study, Eur J Pharmacol, 331, 237-43.

17. Gutzmer R, Langer K, Lisewski M, Mommert S, Rieckborn D, Kapp A et al., 2002, Expression and function of histamine receptors 1 and 2 on human monocyte-derived dendritic cells, J Allergy Clin Immunol, 109, 524-31.

18. Hiraga N, Adachi N, Liu K, Nagaro T, Arai T, 2007, Suppression of inflammatory cell recruitment by histamine receptor stimulation in ischemic rat brains, Eur $J$ Pharmacol, 557, 236-44.

19. Hirasawa N, Ohtsu H, Watanabe T, Ohuchi K, 2002, Enhancement of neutrophil infiltration in histidine decarboxylase-deficient mice, Immunology, 107, 217-21.

20. Hirasawa N, Watanabe M, Mue S, Tsurufuji S, Ohuchi K, 1991, Downward regulation of neutrophil infiltration by endogenous histamine without affecting vascular permeability responses in airpouch-type carrageenin inflammation in rats, Inflammation, 15, 117-26.

21. Holzer P, 1998, Neurogenic vasodilatation and plasma leakage in the skin, Gen Pharmacol, 30, 511.

22. Hua XY, Yaksh TL, 1993, Pharmacology of the effects of bradykinin, serotonin, and histamine on the release of calcitonin gene-related peptide from C-fiber terminals in the rat trachea, $J$ Neurosci, 13,1947-53.

23. Huang JF, Thurmond RL, 2008, The new biology of histamine receptors, Curr Allergy Asthma Rep, 8, 21-7.

24. Ikegami Y, Nishio H, Fukuda T, Nakata Y, Segawa T, 1991, Effect of concanavalin A on intracellular calcium concentration in single blood platelets, Jpn J Pharmacol, 57, 233-41.

25. Jeannin P, Delneste Y, Gosset P, Molet S, Lassalle P, Hamid Q et al., 1994, Histamine induces interleukin-8 secretion by endothelial cells, Blood, 84, 2229-33.

26. Khaksari M, Sajjadi MA, 1999, Effect of verapamil and nifedipine on carrageenan-induced inflammation in the rat paw, J. Kerman University Med. Sci, 6, 191-8.

27. Kolaczkowska E, Seljelid R, Plytycz B, 2001, Role of mast cells in zymosan-induced peritoneal inflammation in Balb/c and mast cell-deficient WBB6F1 mice, $J$ Leukoc Biol, 69, 33-42.

28. Kubes $P$, Kanwar S, 1994, Histamine induces leukocyte rolling in post-capillary venules. A Pselectin-mediated event, J Immunol, 152, 3570-7.

29. Leurs $R$, Church $M K$, Taglialatela $M, 2002, \mathrm{H}_{1}$-antihistamines: inverse agonism, anti-inflammatory actions and cardiac effects, Clin Exp Allergy, 32, 489-98.

30. Lichtenstein $L M$, Gillespie $E, 1975$, The effects of the $\mathrm{H}_{1}$ and $\mathrm{H}_{2}$ antihistamines on "allergic" histamine release and its inhibition by histamine, J Pharmacol Exp Ther, 192, 441-50.

31. Lopes FC, Cavada BS, Pinto VP, Sampaio AH, Gomes JC, 2005, Differential effect of plant lectins on mast cells of different origins, Braz $J$ Med Biol Res, 38, 935-41.

32. Mei $Y$, Wang Y, Xu L, 2007, Suppression of immune-mediated liver injury after vaccination with attenuated pathogenic cells, Immunol Lett, 110, 29-35. 
33. Northover AM, Northover BJ, 1994, Lectin-induced increase in microvascular permeability to colloidal carbon in vitro may involve protein kinase $\mathrm{C}$ activation, Agents Actions, 41, 136-9.

34. Rodler S, Roth M, Nauck M, Tamm M, Block LH, 1995, $\mathrm{Ca}^{2+}$-channel blockers modulate the expression of interleukin- 6 and interleukin-8 genes in human vascular smooth muscle cells, $J$ Mol Cell Cardiol, 27, 2295-302.

35. Rodriguez D, Cavada BS, Abreu-de-Oliveira JT, de-Azevedo-Moreira R, Russo M, 1992, Differences in macrophage stimulation and leukocyte accumulation in response to intraperitoneal administration of glucose/mannose-binding plant lectins, Braz J Med Biol Res, 25, 823-6.

36. Shier WT, Trotter JT 3rd, Reading CL, 1974, Inflammation induced by concanavalin A and other lectins. Proc Soc Exp Biol Med, 146, 590-3.

37. Sirmagul B, Kilic FS, Batu O, Erol K, 2004, The effects of verapamil on stress- and histamineinduced gastric lesions in rats, Methods Find Exp Clin Pharmacol, 26, 763-7.

38. Sirois J, Menard G, Moses AS, Bissonnette EY, 2000, Importance of histamine in the cytokine network in the lung through $\mathrm{H}_{2}$ and $\mathrm{H}_{3}$ receptors: stimulation of IL-10 production, $\mathrm{J}$ Immunol, 164, 2964-70.

39. Stanojević S, Mitić K, Vujić V, Kovačević-Jovanović V, Dimitrijević $M, 2006$, Beta-endorphin differentially affects inflammation in two inbred rat strains, Eur J Pharmacol, 549, 157-65.

40. Stanojević S, Vujić V, Kovačević-Jovanović V, Mitić K, Kosec D, von Hörsten S et al., 2006, Agerelated effect of peptide $\mathrm{YY}$ (PYY) on paw edema in the rat: the function of $Y 1$ receptors on inflammatory cells, Exp Gerontol, 41, 793-9.

41. Stefulj J, Jernej B, Cicin-Sain L, Rinner I, Schauenstein K, 2000, mRNA expression of serotonin receptors in cells of the immune tissues of the rat, Brain Behav Immun, 14, 219-24.

42. Suzuki-Nishimura T, Sano T, Uchida MK, 1989, Effects of benzodiazepines on serotonin release from rat mast cells. Eur J Pharmacol, 167, 75-85

43. Tanaka S, Ichikawa A, 2006, Recent advances in molecular pharmacology of the histamine systems: immune regulatory roles of histamine produced by leukocytes, J Pharmacol Sci, 101, 19-23.

44. Tiegs G, Hentschel J, Wendel A, 1992, A T cell-dependent experimental liver injury in mice inducible by concanavalin A, J Clin Invest, 90, 196-203.

45. Triggiani M, Gentile M, Secondo A, Granata F, Oriente A, Taglialatela M et al., 2001, Histamine induces exocytosis and IL-6 production from human lung macrophages through interaction with $\mathrm{H}_{1}$ receptors, J Immunol, 166, 4083-91.

46. Truneh A, Pearce FL, 1981, Characteristics of and calcium requirements for histamine release from rat peritoneal mast cells treated with concanavalin A, Int Arch Allergy Appl Immunol, 66, 68-75.

47. van der Pouw Kraan TC, Snijders A, Boeije LC, de Groot ER, Alewijnse AE, Leurs $R$ et al., 1998 Histamine inhibits the production of interleukin-12 through interaction with $\mathrm{H}_{2}$ receptors, $J$ Clin Invest, 102, 1866-73.

48. Vannier E, Miller LC, Dinarello CA, 1991, Histamine suppresses gene expression and synthesis of tumor necrosis factor alpha via histamine $\mathrm{H}_{2}$ receptors, $J$ Exp Med, 174, 281-4.

49. Vujić-Redžić V, Dimitrijević M, Stanojević S, Kovačević-Jovanović V, Miletić T, Radulović J, 2000, Peripheral effects of methionine-enkephalin on inflammatory reactions and behavior in the rat, Neuroimmunomodulation, 8, 70-7.

50. Wang KY, Arima N, Higuchi S, Shimajiri S, Tanimoto A, Murata Y et al., 2000, Switch of histamine receptor expression from $\mathrm{H}_{2}$ to $\mathrm{H}_{1}$ during differentiation of monocytes into macrophages, FEBS Lett, 473, 345-8.

51. Xu X, Wei H, Dong Z, Chen Y, Tian Z, 2006, The differential effects of low dose and high dose concanavalin A on cytokine profile and their importance in liver injury, Inflamm Res, 55, 144-52.

52. Yokoyama M, Yokoyama A, Mori S, Takahashi HK, Yoshino T, Watanabe T, et al., 2004, Inducible histamine protects mice from P. acnes-primed and LPS-induced hepatitis through $\mathrm{H}_{2}$-receptor stimulation, Gastroenterology, 127, 892-902. 


\section{RAZLIKE U EDEMU ŠAPE PACOVA INDUKOVANOM KONKANAVALINOM A \\ U ZAVISNOSTI OD SOJA: UTICAJ HISTAMINSKIH $\mathrm{H}_{1}$ I $\mathrm{H}_{2}$ RECEPTORA}

KUŠTRIMOVIĆ NATAŠA, MITIĆ KATARINA, DIMITRIJEVIĆ MIRJANA, VUJIĆ VESNA, KOVAČEVIĆ-JOVANOVIĆ VESNA, MILETIĆ TATJANA i STANOJEVIĆ STANISLAVA

\section{SADRŽAJ}

Testirana je hipoteza da razlike $u$ intenzitetu inflamatornog edema šape indukovanog konkanavalinom A u pacova Dark Agouti (DA) i Albino Oxford (AO) soja potiču od različitog doprinosa histamina i serotonina i njihovih odgovarajućih receptora. Mužjaci pacova DA i AO soja su intraplantarno tretirani antagonistima specifičnih receptora pre izazivanja inflamacije konkanavalinom $A$ i intenzitet inflamacije je praćen merenjem dijametra šape.

Naši rezultati su ukazali da antagonisti histaminskih $\mathrm{H}_{1}$ i $\mathrm{H}_{2}$ receptora smanjuju edem šape indukovan konkanavalinom $A$ u DA pacova, dok antagonist serotoninskih $5 \mathrm{HT}_{3}$ receptora smanjuje edem šape u oba soja pacova. Blokator kalcijumskih kanala ne utiče na inflamaciju izazvanu konkanavalinom $A$.

Razlike $u$ intenzitetu i kinetici inflamatornog odgovora indukovanog konkanavalinom A između DA i AO sojeva su najverovatnije posledica razlika u oslobođenim medijatorima i aktivaciji odgovarajućih receptora nakon injekcije konkanavalina A. 